\title{
A AMAZÔNIA ACREANA DE ABGUAR BASTOS ${ }^{1}$
}

\author{
Gerson Rodrigues de Albuquerque \\ Raquel Alves Ishii \\ Universidade Federal do Acre - Brasil
}

\section{RESUMO}

O objetivo que norteia o presente artigo é desenvolver uma reflexão sobre o "olhar" que o escritor paraense Abguar Bastos Damasceno (1902-1995) lança sobre a Amazônia acreana, no romance "Certos Caminhos do Mundo" (1936). Na narrativa da obra em questão, a cidade de Rio Branco aparece dividida pelo Rio Acre, em duas faces antagônicas: de um lado, Empresa e, do outro lado, Penápolis. Empresa caracterizada como o lugar do vício e Penápolis, local da virtude. No idealizado cenário dessa dupla cidade e da Amazônia acreana sonhada pelo autor, as histórias de Solon, filho do coronel João Gonçalves, e Rubina, uma prostituta negra, irão se entrelaçar. É também entre o vício e a virtude que Abguar Bastos tece a trajetória de outros personagens, marcados, física e moralmente, pelo "estribilho dos falhados e dos sofredores": o Acre. A partir de uma visão determinística, tais personagens surgem aos olhos e subjetividades dos leitores como seres degradados e condenados ao sofrimento no "abismoso reino da solidão".

PALAVRAS-CHAVE: Literatura. Amazônia Acreana. Representação. Discurso. Identidade.

A floresta com seus seres em "estado de selvageria"; o rio com sua "ira implacável", "revolto", "violento"; a cidade com suas "casas toscas", "homens rudes", "bêbados", "carentes de civilização". A floresta, o rio e a cidade têm acompanhado a percepção de diferentes poetas, músicos, romancistas, jornalistas, viajantes e outros escribas em representações sobre a Amazônia acreana. A rigor segue-se o mesmo repertório delineador de uma "Amazônia inventada", na formulação de Neide Gondim (1994), como um singular e primitivo mundo sem cultura e sem história.

1 Versão alterada de Comunicação publicada nos Anais do IV Simpósio Linguagens e Identidades da/na Amazônia Sul-Ocidental, realizado no ano de 2010, no Campus Universitário da UFAC. 
Acompanhando as construções literárias de Abguar Bastos, ${ }^{2}$ reencontramos esses temas centrais de "nossa cultura letrada". Em "Certos caminhos do mundo", o idealizado espaço da trama se estabelece em meio às águas e terras firmes de cidades regidas pela floresta e com a floresta que é parte inalienável das "urbanidades" e "ruralidades" nas Amazônias acreanas. Dentre os aspectos consideráveis dos cenários imaginados por esse autor, estão inseridos os pontos de articulação/desarticulação das duas margens do rio Acre, onde atualmente se movimenta a cidade de Rio Branco: Empresa e Penápolis, dando consistência aos dois mundos criados pelo autor: "duas cidades" separadas e unidas pelo mesmo fluxo. No âmago visceral dos "territórios" dessas "cidades", "o vício desafia a virtude" e, sob a mediação das águas e dos barrancos do rio, ambas se encontram "no mais hediondo e feroz beijo do mundo" (DAMASCENO, 1936, p. 73).

Abguar Bastos faz circular sua visão de história e geografia por intermédio de um texto ficcional no qual suas personagens assumem os postos de personagens históricos. Nesse mesmo estreito caminho, suas personagens da história ganham os postos de personagens da ficção. Sua visão de história é linear, seu tempo histórico é linear; seu tempo ficcional é cronologicamente embasado nessa linearidade.

Beatriz Sarlo nos adverte que o texto literário ou, mais precisamente, a literatura "opina, com excessos de figuração ou imaginação ficcional, sobre história e política” (SARLO, 1997, p. 28). Inspirados nessa assertiva apreendemos que apegado à ficcional narrativa épica de um "Acre que se fez brasileiro", Abguar Bastos arremessa suas representações aos leitores. Representações tecidas nas belas e rudes palavras de um enredo imerso na retórica amazonialista e no fundante discurso da conquista do "deserto selvagem": o "distante" e "solitário"

2 Abguar Bastos Damasceno (1902-1995), jornalista, historiador, poeta e romancista paraense. 
Acre, sinônimo de "beribéri, impaludismo, amarelão... Mortos. Mais mortos. Os rios correndo. Lameirões sêcos, esverdeados. Mosquitos negros, zumbindo..." (DAMASCENO, 1936, p. 48). Seus estereótipos, como signos da conquista dos "sertões", vão se "naturalizando" em meio ao à floresta e seus seres.

No Acre, geográfica e historicamente sonhado nas páginas de "Certos caminhos do mundo", mulheres e homens aparecem como personagens fantasmagóricos em um mundo fantasmagórico. São seres "melancólicos", "egoístas", "silenciados", "prisioneiros do destino", em meio ao "dilúvio" das "chuvas coléricas" e das "árvores tentaculares" (DAMASCENO, 1936, p. 52). Naquelas "distantes" e "solitárias" paragens somente o forte sobrevive: "oprimido" e "imobilizado" pelas distâncias, "no rebôjo das cachoeiras, no intestino das selvas, no ventre festivo dos vilarejos, de fóz a fóz, existe o rumôr alviçareiro da luta pela vida e um resfolegar coletivo de rebanho humano, em marcha" (DAMASCENO, 1936, p. 58). Prossegue a pena ligeira e implacável de Abguar Bastos.

Ecoando percepções e leituras sobre os mundos amazônicos, presentes em inúmeros relatos de viagem, lavrados por diferentes homens e mulheres de ciência que passaram pelos rios e cidades amazônicas, o enredo de Abguar Bastos é impregnado não da crença romântica de um re-encontro do homem com a natureza, mas da perspectiva de uma natureza ameaçadora, reguladora, condutora da vida. Em meio a essa perspectiva, o autor delineia a trajetória de Solon, filho do coronel João Gonçalves que morre deixando navios e seringais no Acre. Solon vende as terras e navios do pai, deixa o Pará e vai para o Rio de Janeiro. Depois de algum tempo retorna à Belém e lá conhece um holandês, Ronie, que lhe propõe sociedade. Encantado por Chandla, a esposa do holandês, Solon aceita a proposta. No entanto, acaba caindo numa cilada e perde tudo. 
No entanto, ainda em Belém, Solon é convidado por um amigo de seu pai a administrar o navio "República", que está prestes a partir para o Território Federal do Acre. Prontamente ele aceita. No Acre, inicia um romance com Rubina, uma acreana como ele. Rubina conhece "Princesa", que a introduz no "vício da cocaína". Durante o tempo em que Solon permanece no Acre, vários "causos" são contados; histórias de "tipos humanos" que habitam aquela parte do "território nacional". Quando Solon percebe o "vício" de sua amante Rubina, tenta levá-la em sua viagem de volta à Belém. Entretanto, os dois não conseguem chegar ao seu destino, em razão de um naufrágio suicida. Como desenlace do romance, Solon salva Rubina e ambos se embrenham na floresta; são "devorados pela floresta".

Embora numa perspectiva evolutiva, o tempo linear da narrativa é quebrado a partir do terceiro capítulo, quando Bastos recorre a uma analepse, produzindo uma interrupção na trajetória das personagens e conduzindo o leitor para um período histórico anterior ao do que está contextualizada a sua trama: o do "surgimento" e "incorporação do Acre ao Brasil". Nesse deslocamento espacial, articulando um "passado" e um "presente", como dados fechados em si e homogêneos, o autor situa as duas cidades por ele imaginadas em eterna disputa. Essa quebra da narrativa segue até o sétimo capítulo (note-se a presença de 18 capítulos ao todo). A partir do capítulo oitavo a linearidade é retomada.

Para o Abguar Bastos, a "recuperação de acontecimentos" passados, tem por objetivo explicar o presente do que ocorre na narrativa. Tais "acontecimentos" são ordenados de modo a dar sentido às origens da personagem principal: Solon. É o regresso do "filho pródigo" ao lugar onde ele nasceu: regresso ao Acre, em especial Penápolis. Um lugar onde seu pai enriqueceu e cuja "história" precisava ser "contada". 
Nessa "retomada" de um "tempo passado", como algo mítico, intocável e inalterável pelo presente, surge o cenário das faces rivais da capital do Território do Acre: Empresa e Penápolis. A primeira caracterizada como o lugar do vício, e a segunda como o lugar da virtude. Cada uma ficava numa margem do rio. Penápolis era o lugar onde Solon nascera. Mais tarde, no decorrer da narrativa, revela-se que a amante de Solon, Rubina, nascera em Empresa. Não por acaso Rubina se entregara ao "vício da cocaína". É flagrante, em certos trechos da obra, o empenho do autor em justificar o comportamento de suas personagens, utilizando-se de concepções determinísticas com base na geografia, genética ou no meio e condições em que vivem.

A narrativa está contextualizada no decorrer dos anos 1920, especificamente, em sua primeira metade. Os cenários em que circulam as personagens oscilam entre as cidades de Belém, Xapuri, Rio Branco, e os rios Acre e Purus - por onde percorrem barcos e navios - e suas margens. Inevitavelmente, o Acre se constitui como o cenário predominante, onde as personagens centram-se no espectro de Empresa e Penápolis. Nesses "ambientes urbanos" circulam comerciantes, seringueiros, estrangeiros, prostitutas, castanheiros, entre outros.

Por meio de determinadas escolhas lexicais, o narrador do romance revela seus valores não apenas morais, mas políticos, na acepção mais ampla dessa palavra. Ao enfatizar esse aspecto, devemos deixar claro que pensamos o romance e suas formas estéticas e culturais - seu poder de produzir percepções de mundo e de julgamento do "outro" e de si pelos leitores -, acompanhando a perspectiva cunhada por Edward Said (1995), para quem a literatura - e qualquer forma de manifestação artística ou de obra de arte - está prenhe das subjetividades, valores, contradições, anseios e projetos do mundo em que vivem seus autores. A literatura, as obras de arte ou as expressões da 
cultura, como preferem alguns, não são autônomas e, especialmente, seus autores estão "profundamente ligados à história de suas sociedades, moldando e sendo moldados por essa história e suas experiências sociais em diferentes graus" (SAID, 1995, p. 23).

Em "Certos caminhos do mundo", o Acre é visto como um lugar difícil de viver, um inferno que desafia o homem, de maneira que "só é possível viver aos brados, para que se tenha a impressão de não estar afogado, nem perdido" (DAMASCENO, 1936, p. 51). Nesse diapasão, isento de qualquer ingenuidade, segue Abguar Bastos:

Só procura o Acre quem é órfão de consolação, quem naufraga e se desilude, quem grita por socorro e, em troca, só vê, nas mascaras de granito, a indiferença desoladora dos homens. Ninguém busca o Território com intenção de sobreviver. A perspectiva é sempre do suicídio. (...) O refugiado resolve ficar, mas sujeita-se a adaptação, sob pena de ser esquecido pela terra que o mundo esqueceu (DAMASCENO, 1936, p. 57).

$\mathrm{O}$ próprio nome da terra, segundo o autor, antecipa as agruras daqueles que para lá se deslocam, posto que "já revelava o tumulto inscrito no seu nome de batismo, esse nome onomatopaico e duro, impressionante e ríspido, que é o anátema do boliviano - o Acre! A terra apresentava sem rebuços todas as qualidades adivinhadas nesse título de aspereza invulgar" (DAMASCENO, 1936, p. 52). Chama atenção que, na intensa dicotomia entre sociedade e natureza - o eixo norteador escolhido para constituir a narrativa -, Abguar Bastos imagina um ambiente em que prevalece toda sorte de infortúnios e de degradação moral, como sinônimo de Acre, um "lugar amaldiçoado" desde a sua gênese; o "fim do mundo", a "praga" deixada pelos bolivianos: "na frente o paroxismo solar e na retaguarda o estridor das feras, eis o espetáculo inicial da vida, do vale do Purús ao vale do Juruá" (DAMASCENO, 1936, p. 52). 
Leitor de Euclides da Cunha - que insere em seu texto -, Abguar Bastos tomou para si as teses do mesmo, reafirmando que em meio à natureza hostil, subjugando os fracos com sua "seleção telúrica", entrar e sair do Acre significava tornar-se "capaz de todos os sofrimentos", posto que, "com isto nada mais há em que experimenta-lo" (DAMASCENO, 1936, p. 64). Naquela Amazônia acreana, re-imaginada por Bastos, perante as forças da natureza, o homem adaptava-se, era moldado para não sucumbir e também para viver em eterno conflito pela sobrevivência, pelo "direito" de explorar aquela terra que o talhava pela "experimentação". Interessante observar que a descoberta da não passividade da natureza perante a exploração do homem, conferiu à mesma o status de um sujeito determinante - espécie de senso comum em diferentes obras que constituem um ideário de Amazônia una, homogênea. A natureza, assim pensada, faz do homem um ser pequeno, "impotente diante de sua magnitude", de sua "vontade". Como um "sujeito dotado de vontade", a "natureza se vinga", incessantemente, daquele que a explora: é o "inferno verde" "engolindo os homens", "devorando suas almas".

\section{Os sujeitos "coisificados" da Amazônia sonhada por Abguar Bastos}

Em fins dos anos 1910 e na década seguinte, especialmente, com a "fundação" do Instituto Histórico e Geográfico do Acre (IHGA) e a invejável dedicação com que diferentes jornalistas e outros escritores se empenharam em produzir a narrativa da "conquista do Acre" e sua "anexação ao Brasil", instituiu-se de um discurso da "origem do Acre", fruto de "heroísmo de desbravadores nordestinos" ou, mais precisamente, cearenses e daqueles que, liderados por Plácido de Castro, fizeram a "Revolução Acreana". Tema polêmico, alvo de intensos comentários nos diários de notícias de Belém, Manaus e, principal- 
mente, Rio de Janeiro, a capital da república, a "saga dos brasileiros do Acre", não passaria despercebida por Abguar Bastos.

O Acre, "território boliviano" fazia parte do universo mental dos estadistas brasileiros, no início do período republicano. Era a marca da política internacional do Brasil, seguindo os princípios do Tratado de Ayacucho (1867), que estabelecera limites para o "conhecido", mas, principalmente, para o "desconhecido": as "tierras non descubiertas", os "territórios de colônia". As terras, rios e florestas que seriam batizadas com o termo "Acre" "eram bolivianas", como registravam as "fantasias" cartográficas de mapas desenhados por homens que jamais colocaram os pés na Amazônia, no dizer de Euclides da Cunha em seu relato da viagem pelo rio Purus, na condição de chefe da delegação brasileira na Comissão Mista de Demarcação da Fronteira do Brasil com o Peru (CUNHA, 1986).

"O dono da terra era o boliviano". Com essas palavras secas, diretas, Abguar Bastos abre o terceiro capítulo de "Certos caminhos do mundo". Porém, o "dono da terra" não a possuía, arremata em seguida, com a ênfase de seu estilo literário, para situar a desventura de "aventureiros bolivianos" que:

desciam dos planaltos nevados e vinham pelo 'caminho das cabras' até o Bení. Depois de dois mezes chegavam ao Orton. O Orton era um rio côr de bronze, devido á sombra pesada da floresta. (...) O sol faulhava, queimava os homens. Uma fortaleza de luz atirava os seus raios por todos os lados. (...) Os aventureiros continuavam na sua marcha, muitas vezes desenterrando os pés da lama para secá-los adiante com a canícula e lavá-los depois na agua dos rios. (...) Em seguida as matas enguliam, com a sua bôca de sessenta leguas, esses estranhos viajantes (DAMASCENO, 1936, p. 44).

A sensibilidade e o esplendor das belas imagens construídas por Abguar Bastos devem se ressaltadas e apreciadas por todos nós que o lemos. Porém, não podemos deixar de antever seu caráter secular, os 
enfrentamos experimentados pelo autor, na confluência dos interesses e na tomada de posição frente às questões de seu tempo presente. História e política estão imbricadas em sua criação literária, no específico e histórico contexto de criação da "epopéia do Acre". Sigamos, com Abguar Bastos, a trajetória dos bolivianos, os "donos da terra" que, aos transpor as "inacreditáveis fronteiras" do Acre, encontrariam:

aqui e acolá, homens de côr branca, sujos, magros, um pouco ferozes. Vinham do Brasil e se diziam filhos duma terra muito longe que se chamava Ceará. Os bolivianos não deixavam de comentar a presença desses selvagens e ainda que já parecessem tribus, (tão importantes iam se tornando seus agrupamentos), não sobrava tempo para que fossem examinados os seus propósitos. (...) Enquanto esses exquisitos homens nómades aí permaneciam, os bolivianos, cobertos de pó e feridas, roídos pelos mosquitos e descarnados pela febre, retrocediam e, aos pares, reapareciam nas estradas de Cobija. Era o regresso. (...) Retornavam ao lar, sim. Mas, donde vinham? Do Acre! Era como se viessem do deserto. Surgiam aos olhos da família mais velhos, mais trôpegos, sem vontade p'ra nada. (...) Ao cheiro da roupa misturava-se o almiscar das onças e o suor dos muares. A mochila em frangalhos. Os sapatos esburacados. As armas inuteis. A péle sêca, de mumia. (...) No meio dos amigos e dos filhos, a fébre assaltava-os. Eles gritavam que iam morrer e todos, indistintamente, olhavam para fóra, na direção da terra intransponível. (...) Então as mães abraçavam os filhos e pediam, com os olhos molhados, que ninguem fôsse para o Acre (DAMASCENO, 1936, p. 44-46).

Seguindo os passos de Gilles Deleuze e Felix Guattari, Eugênia Vilela no ensina que o "pensamento é uma cartografia do tempo e do espaço, a compreensão é a espessura dos lugares. Sem a retórica da história como ficção do presente". Pontuando a urgente necessidade de se produzir uma história que não seja a do aparelho do Estado e da ideia de progresso e desenvolvimento, nos adverte Vilela: "as grandes narrativas têm falhas, são ficções da memória e do sentido" (VILELA, 2001, p. 233).

Essas "ficções da memória e do sentido" compõem o pano de 
fundo do cenário sob o qual Abguar Bastos produz seu "romance histórico", pois, os paradoxos da narrativa histórica se fazem presentes em seu texto ficcional. Mas, o autor de "Certos caminhos do mundo" não está interessado com a história e, muito menos, em explicações para os dilemas da mesma e aproveita para destilar seu ficcional desdém e indiferença em relação ao "boliviano". Desdém e indiferença constituídos historicamente e fecundados no imaginário dos "acreanos", "desde sempre" habitantes dessas terras. Desqualificando a capacidade do "boliviano" em progredir no meio das adversidades da terra, com "naturalidade" idêntica à que o reconhece como "legítimo dono" da mesma, Abguar Bastos apresenta uma das "provas mais irrefutáveis" de sua narrativa, enfatizando que aquela "terra não tinha amôr ao seu dono. Com as suas florestas desgrenhadas e as suas sombras lascivas, preferia entregar-se ao extrangeiro que vinha do Brasil com o cheiro do mar nas carnes rijas" (DAMASCENO, 1936, p. 47).

Os estereótipos presentes na caracterização do "boliviano", imaginado por Bastos, também são lançados para a imagem do "cearense" e diversos outros "tipos" ou arquétipos, em seu sentido psicológico, presentes na obra. Negros, indígenas, mulheres, ladrões, leprosos, assassinos e estrangeiros, são construtos do retrato de um Acre pintado e regulado pela lógica que re-produz uma visão inferiorizada do "outro", com base num modelo ideal de civilização e de comportamento moral e religioso advindos de uma matriz européia "civilizadora" e colonizadora de corpos e mentes.

$\mathrm{Na}$ fabulosa narrativa de um "Acre que lutou para ser parte do Brasil", aprendemos, desde os primeiros anos de escola, a "encher o peito de nobreza, orgulho e amor", nos versos do patriótico hino acreano. Dessa invenção fantástica, urdida pela saga de pessoas oriundas de um mundo também inventado, o "nordeste" (ALBUQUERQUE JÚNIOR, 2009), aprendemos a história de antepassados que "domaram 
os sertões", "amansaram a terra" e fizeram a revolução que nos livrou da "opressão boliviana" e de um cartel internacional, o "Bolivian Sindicaty". ${ }^{3}$

Merece destaque, no entanto, que o cearense, representado nas alegorias de Abguar Bastos, é um homem "branco", "magro", "sujo", "feroz", "selvagem", que vem ao Acre e, apesar de sua condição física, resiste aos obstáculos da "selva", fincando-se na terra, ajudando-a a tornar-se independente. Segundo o autor, o cearense diferencia-se do boliviano, pois o mesmo se adapta à terra. Curiosamente, a "descendência sem propósito", segundo a narrativa épica, da maior parte do "povo acreano" aparece bestializada, coisificada, estereotipada em múltiplas dimensões. Mais que isso, em "Certos caminhos do mundo", as representações construídas carregam os estigmas de "culturas que são, por natureza, condenadas à colonização", no dizer de Homi Bhabha, posto que ao apresentar "uma população de tipos degenerados" o faz por meio do "regime de verdade", servindo como pretexto de interferência externa (BHABHA, 2005, p. 111). É o que vai se observar ao longo da narrativa com a presença de um discurso que legitima a exploração dos serviços de navegação, nos rios da região, por empresas oriundas de países estrangeiros, ou seja, as "nações amigas" que tanto lutaram pela abertura dos portos e navegação pelos rios amazônicos.

As imagens da "Amazônia" como um "vazio demográfico" ou um grande e "solitário deserto de homens", sempre acompanharam os discursos que nortearam a produção de uma certa identidade à região. Abguar Bastos segue esse pressuposto "naturalizado" ao longo dos tempos e, conflituosamente, internalizado pelas sociedades amazônicas. Em "Certos caminhos do mundo", o cearense é visto como

3 Essas fantasias históricas, sob a forma de insistentes campanhas publicitárias do governo do Acre dos tempos presentes, intentam enclausurar a imaginação de todos com o medíocre "orgulho de ser acreano". 
o responsável por estabelecer "o primeiro sinal de humanidade" nas paisagens das Amazônias acreanas, dando consistência não apenas a uma "ausência de humanidade" aos diferentes grupos indígenas que habitavam a região, mas a uma completa indiferença em relação às suas existências.

No "romance do Acre", os indígenas são alvo de um julgamento que os singulariza na condição de "animais" a serem governados e destinados à execução dos "serviços sujos" e trabalhos pesados. A narrativa ficcional do autor segue a mesma trilha da narrativa oficial do processo de "colonização" e "conquista" do Acre, na qual as sociedades indígenas foram alvo de inúmeras violências e incorporadas como mão-de-obra escrava, destinada aos trabalhos pesados e perigosos, ao carregamento de mantimentos e produtos oriundos do extrativismo, abertura de estradas, caça e pesca, retirada de madeira e produção de borracha. Aos colonizadores identificados ou auto-identificados como brancos, recaiam os trabalhos intelectuais como pensar, projetar, coordenar, gerenciar ou comandar as ações. Dessa forma foram estabelecidas as hierarquias e as relações na divisão do trabalho, conforme os padrões colonialistas. No texto de Abguar Bastos, os vocábulos presentes na "conquista do novo mundo" chamam a atenção, especialmente, quando identificam como "mansos" os índios que não oferecem resistência ao "mundo do trabalho" e "maus" aqueles que se recusam a aceitá-lo.

No entanto, "mansos" ou "maus", "civilizáveis" ou "arredios", as representações imagéticas de Bastos, ampliam o fosso do desconhecimento de uma humanidade aos indígenas, posto que são caracterizados como "selvagens" ou habitantes do "vazio de civilização". Mais que isso, é necessário levar em consideração que descaracterizá-los como seres humanos e habitantes de uma terra que estava - e continua - sendo disputada pela expansão da chamada "sociedade nacional" e 
"internacional", fazia parte da "luta pela geografia", nos dizeres de Said, destacando que tal luta "é complexa e interessante porque não se restringe a soldados e canhões, abrangendo também idéias, formas, imagens e representações" (SAID, 1995, p. 38).

Também ganha relevância, no texto de Abguar Bastos, as metáforas que produz sobre a condição feminina. Isso fica evidente quando o mesmo se refere à floresta que se entrega cheia de "lascívia" ao amante "estrangeiro", numa construção literária impregnada da carga de valores morais responsável pela cristalizada noção de vulgaridade e prostituição com que são vistas e tratadas as mulheres da Amazônia acreana:

frúta do Acre! Tanto fazia cravar o dente na terra ou no fruto, logo espirrava para dentro da garganta o sumo que se transformava em ebriez! Terra - mulher que se entregava ao extrangeiro, mulheres da mesma argila que prendiam os forasteiros! Os barrancos duros, petreos, severos, pareciam os homens que vinham do Acre! As praias longas, sinuosas, delgadas, pareciam mulheres deitadas, acolhendo o naufrágio dos homens! (DAMASCENO, 1936, p. 221).

A acentuada virilidade da narrativa histórica, presente na "epopéia da conquista do Acre", deixou marcas profundas na imaginação ficcional do autor de "Certos caminhos do mundo". A intensidade dessa "masculinidade desbravadora" ganha proporções maiores quando da descrição da personagem Princesa, a prostituta negra que inicia Rubina no uso da cocaína. Nesse momento, aparece de forma intensa a coisificação da mulher pela problemática da cor e da "raça", vista como nada além de um "belo pedaço de carne", nas palavras de Bastos “a 'Princesa' era uma negra bonita e tinha uma presença espetacular. Era uma negra admirável, inveja da raça, puro sangue dos trópicos. Maravilhosa, até. Podia ficar célebre se vivesse nos tempos do poeta Baudelaire" (DAMASCENO, 1936, p. 165-166).

Em outra passagem do texto, num diálogo entre Princesa e o 
promotor público, após um desentendimento por causa dos versos que o poeta Juvenal Antunes dedica à Princesa, o promotor se levanta e, ao retirar-se do ambiente, grita: "Este Acre é uma novidade. Negro, aqui, quando não dá pra feder, dá pra entender de arte" (DAMASCENO, 1936, p. 166). Em seguida, nenhum comentário, tornando transparente a naturalidade com que o autor lida e reforça em sua estética os estereótipos de senso comum, as tradicionais pilhérias sobre o negro na Amazônia acreana. Chama a atenção, ainda, o cargo de promotor público, exercido pelo homem que ofende a personagem Princesa. As hierarquias aqui, não são ingênuas, pois, o que irá predominar será o juízo feito pelo poder constituído e não o de uma mulher, negra e prostituta.

A outra personagem feminina de destaque na obra é Rubina. Também negra e órfã de pai e mãe, ela crescera na casa de um tio e frequentara escolas na cidade de Rio Branco. Gostava de ler e falar com pessoas que considerava "mais entendidas". Acabou casando com um cearense. Um casamento que, nas linhas traçadas pelo autor, "fora uma barbaridade praticada pelo Destino contra uma indefesa criatura" (DAMASCENO, 1936, p. 195). Aqui o casamento é visto como o pior dos males sofridos por Rubina e ela, desprovida de vontade própria, à mercê de um destino que, tratado como senhor de tudo e de todos a resignara à condição de "coitada" e "indefesa criatura".

A fantasia da vítima, artimanha do jogo de palavras que, na literatura patriarcal, insiste em representar a mulher como um ser passivo, no dizer de Mary Pratt (1999), se manifesta na lírica de Bastos mesmo quando Rubina se ergue contra a "barbaridade" do casamento e "foge" para Xapuri onde se torna "amante" e depois abandona Fadul, um homem "agressivo" e "ciumento". Ao conhecer Solon e com ele passar a viver um intenso romance, a imagem de Rubina é caracterizada pela representação de uma mulher a quem a vida concedeu nova oportu- 
nidade, mas o destino criado por uma subjetividade determinística a conduz ao encontro de Princesa, que lhe seduz ao consumo de cocaína e a retornar ao seu lugar de origem no enredo do autor: estava "condenada à perdição", sua origem a condenava.

Em meio ao desenrolar da trama, o maniqueísmo e a dualidade entre bem e mal pedem passagem a todo instante. É a partir dessa noção dual que as personagens, em especial as femininas, são enclausuradas, numa natureza de sublime e profunda letargia que alcança as mulheres da Amazônia acreana, com seus "demônios" que anseiam o despertar da "maldade".

$\mathrm{O}$ amôr póde ser poderoso. $\mathrm{O}$ coração póde reinar. O espírito póde pairar acima das miserias humanas. Mas a furia dos sentidos hereditarios, a revolução dos instintos desenfreados, só a morte póde vencê-los. O predominio do atavismo e das forças correlatas ás tendencias do meio, é uma viscosa mão que arrasta os seres ao suplicio, ainda que um clarão de tragedia amacie a fauce dos abismos. O Demonio está em nós, e dorme. A's vêses é um sono letargico, ás vêses é um sono leve. Porém, se alguma coisa o acorda, cuidado com êle, porque muitas vêses acontece não dormir mais. Si a maldade chega e encontra o nosso Demonio dormindo, ainda temos força para reagir. Porém, si ela o depara acordado, ei-lo agarrando-a com ambas as mãos e com ela transformada a ingenuidade das almas. Durante o sono letargico, por mais que a maldade martéle, nada desperta o Demonio. Mas si o sono é leve, não haja consentimento para que as marteladas ressôem, pois, em verdade, com duas ou três, ele abre os olhos. O Demonio de Rubina estava acordado (DAMASCENO, 1936, p. 215-216).

Com essas significativas construções literárias, Abguar Bastos nos premia com seu gênio literário e nos possibilita uma viagem por seu imaginário. Não o imaginário de uma realidade ficcional, uma não -realidade, mas o imaginário daqueles que enfeixaram as Amazônias acreanas em um conjunto de reduções deterministas: a terra, o rio, a floresta, a genética, a solidão, a distância. Não é nas realidades amazônicas que as palavras do autor estão assentadas, mas no imaginá- 
rio daqueles que as sonharam, projetaram, fantasiaram, identificaram, planejaram, governaram, representaram.

Não por acaso no romance de Rubina, com Solon, personagens que dominam o enredo de "Certos caminhos do mundo", as duas faces da cidade de Rio Branco retornam com força surpreendente nas adjetivações com as quais seu autor as imagina: Empresa, de onde vinha Rubina, era o lugar do vício e estava condenada ao seu exercício, pela geografia e pela genética; Penápolis, o da virtude que deveria sempre conduzir os pensamentos e as ações de seus homens e mulheres, da mesma maneira determinados pelo meio e pela genética.

No exame psicológico das personagens, feito pelo autor, o "Demonio de Rubina estava acordado", assim como estavam acordados os "Demônios" das prostitutas e da quase totalidade dos homens de Empresa, local onde reinava uma

excitante vida noturna. Aos domingos funciona o cinema. Vêm-se marafonas enchapeladas nos camarotes e senhoras honestas, afrontadas, timidamente, nas cadeiras de fila. Cruzam-se nas ruas o rebanho e a mátula, profissionais de jogo, "camelots", ganadeiros, marítimos, contratadores de seringa, contrabandistas, vendedores de cóca. (...) É o bairro das prostitutas. Ás vezes, um clarim de alegria espanta a miseria d'alguns quartos. O "coronel" se apresenta, convida. No dia seguinte uma das mulheres se muda do bairro, vai morar noutra rua, toma um jeito reservado de gente distinta, tudo por conta do "coronel". Ás vezes, a melancolia assalta-a. Foge ás escondidas e volta ao bairro, só para ver. Acontece, porém, por esquecimento, não retornar á nobreza da vida limpa. Prefere mesmo o charco, a bagunça. Prefere o panorama humido do capinzal, a iluminação dos vágalumes e a musica dos grilos (DAMASCENO, 1936, p. 66-69).

A escolha dos termos, os adjetivos com os quais Abguar Bastos vai apresentado suas personagens, expressam suas escolhas e concepções de mundo. "Princesa", "Rubina", "Flavia", as "bonecas de trapos", enfim, a quase totalidade das mulheres de seu "romance do 
Acre" são "degeneradas", "condenadas pela natureza" a viverem no "charco", na "bagunça" daquele lado da cidade - Empresa - que é o próprio vício. Por entre essas "degeneradas", o autor faz desfilar um conjunto de seres estereotipados, riscados por uma pena que coisifica e reduz sujeitos e modos de vida ao sabor de uma retórica moralista e preconceituosa: rebanhos humanos, objetos das privadas, jogadores profissionais, camelôs, guardadores de cabras e porcos, marinheiros, seringueiros, castanheiros, contrabandistas, traficantes.

Empresa era a "vergonha" de Penápolis, contudo deveria ser por ela "carregada", visto que entre as duas faces da cidade havia uma interdependência. Em Empresa estava o comércio; em Penápolis, os consumidores. No final do romance, para livrar sua amante do "vício da cocaína", Solon percebe que a única saída era tirá-la do Acre, sair daquele lugar que o assombrava com suas histórias e que parecia ser a causa de todos os seus males. Entretanto, Solon não podia determinar qual seria a sorte de Rubina; não tinha como lutar contra seu destino. Assim, pouco tempo depois de tê-la encontrado com outro homem, o Jorge, em uma das cabines do navio "República" e, furiosamente, ter conduzido essa embarcação para o naufrágio, Solon, provido das virtudes do "sopro de civilização" daqueles que nasceram em Penápolis, ele a livra da morte e, debruçado sobre o corpo daquele "fruto da terra", tece o final do drama que protagoniza:

Arrancara-a da terra bárbara, mas logo a perdera. Perdida! E como houvesse compreendido, duma vez para sempre, que ela era uma filha do mundo sem dono e que desse mundo ingrato e estranho nada se pode roubar sem castigo, pôs-se com pena a alisar-lhe os cabelos (DAMASCENO, 1936, p. 251).

Abguar Bastos se refere a um "mundo sem dono"; ao Acre, uma "terra sem dono", formatando a idéia de que o homem que vai para a Amazônia acreana paga um preço: a solidão, a miséria, a loucura, a morte. E Solon, não era diferente. Ele tentou fugir com Rubina, sair 
daquela região, daquele rio que os vinculava a uma terra "não civilizada". Porém, não conseguiu, não podia retirá-la da terra; não podia negar a origem de Rubina, uma origem "enlameada" pelo lugar em que nascera e pelas pessoas com as quais convivera, com seus "instintos" e "propensão ao vício".

Desse modo, o preço que Solon teve que pagar por ousar "roubar" da terra um de seus "frutos", foi a ruína nos negócios, novamente a ruína. Quando ele começa a alisar os cabelos da amante, já no final do romance, é como se tivesse se conformado. Foi derrotado, pois esse era o destino dos seres dessa terra "vazia" e porque novamente se rendera à paixão desmedida, posto que, também, foi por causa de uma mulher que perdera a herança do pai para o holandês "vigarista", no início do romance. Solon se encantara por Chandla, deixou-se levar por seu perfume, por seu jeito enigmático e perdera tudo.

Ao longo de "Certos caminhos do mundo", Abguar Bastos prende-se a uma visão que julga e define as relações sociais no Acre, de modo a revelar as vozes que devem ser privilegiadas (homem, promotor, coronel, governador) em detrimento do silêncio daqueles que apenas compõem o cenário "exótico" e "caótico" da região (mulheres, amantes, prostitutas, viciados, ladrões, leprosos, seringueiros, negros e índios). Todos "polidos" por um ambiente natural que "nada deixa antecipar". Ali, nos cenários pintados por sua criatividade, surge um Acre onde "tudo é febre, além da febre do corpo. Febre nas marchas, febre no trabalho, febre nos desejos, febre em todas as paixões, febre torrencial, escarlate, profundamente cósmica" (DAMASCENO, 1936, p. 62).

\section{Considerações finais}

Vivemos num mundo de mercadorias, de mercado e de consumo, mas, também de representações, afirma Edward Said, e "as representa- 
ções - sua produção, circulação, história e interpretação - constituem o próprio elemento da cultura". Toda representação é marcada por duas esferas: a cultural e a política, insiste, enfatizando que, embora essas esferas sejam insistentemente tomadas em separado pelo pensamento acadêmico, "não apenas estão relacionadas, como, em última análise, são a mesma coisa". Para ele, a separação entre a esfera cultural e a política somente pode se operar mediante um "radical falseamento", no qual a

cultura é exonerada de qualquer envolvimento com o poder, as representações são consideradas apenas como imagens apolíticas a ser analisadas e interpretadas como outras tantas gramáticas intercambiáveis, e julga-se que há um divórcio absoluto entre o passado e o presente (SAID, 1995, 93).

Nas escolhas lexicais, nos adjetivos, na estética, no estilo literário ou na psicologia de Abguar Bastos, em "Certos caminhos do mundo" não existe ingenuidade. O próprio gênero literário, o romance, a partir do qual o autor tece suas representações sobre a Amazônia acreana, é parte inexorável de suas escolhas, sua perspectiva. O surgimento do romance, enquanto gênero literário é datado e profundamente vinculado à expansão da sociedade de mercado e do "mundo do trabalho" industrializado. Retornemos às ponderações de Edward Said:

Entre todas as principais formas literárias, o romance é a mais recente, seu surgimento é o mais datável, sua ocorrência, a mais ocidental, seu modelo normativo de autoridade social, o mais estruturado; (...) O romance é uma forma cultural incorporadora, de tipo enciclopédico. Dentro dele se encontram tanto um mecanismo altamente preciso de enredo quanto um sistema inteiro de referência social que depende das instituições existentes da sociedade burguesa, de sua autoridade e poder" (SAID, 1995, p. 109).

Acompanhando as reflexões desse autor, apreendemos, em "Certos caminhos do mundo", uma "torrente avassaladora" de construções mentais que definem uma dada estrutura à Amazônia acreana. Seu tom irônico, suas metáforas, suas construções gramaticais, sua narrativa 
histórico/ficcional ou ficcional/histórico da "nação" que se expande pelos "territórios inexplorados dos sertões amazônicos" são poderosas representações, síntese de um lugar/olhar "civilizado" conceituando a "barbárie".

Em Abguar Bastos prevalece a sedução do "olhar viajante", aquele que olha e não vê; julga não a partir do que vê, mas do que sente, dos valores que professa, filtrando o "outro" pela ótica de suas próprias crenças, valores morais, opções políticas. No (des)encontro entre o que vê/julga e o que é visto/julgado se estabelece uma hierarquia não apenas de poder e mando, posto que isso é constituído nos entrechoques das subjetividades - cujos resultados são sempre imprevisíveis. Mas, uma supremacia mediada pelas diferenças culturais, pelo predomínio da escrita, pelas artimanhas de uma sociedade que produz e faz circular mercadorias e representações. Nessa lógica vemos/ouvimos o ressoar dos conhecidos determinismos, das vozes e dos textos que alimentam seu discurso, transformando as sociedades humanas e os seres do "mundo natural" amazônico em "coisas" e "objetos" de um meio "fantástico", "inenarrável”, no qual "os instintos limitam-se com a barbárie".

\section{THE ACREAN AMAZON IN ABGUAR BASTOS}

\section{ABSTRACT}

The main objective of this paper is to develop a reflection on the "look" that the writer Abguar Bastos Damasceno (1902-1995) builds upon the reality of the State of Acre, in the Brazilian Amazon region, depicted in the novel "Certos caminhos do mundo" (1936). In the novel, the city of Rio Branco appears divided by the Rio Acre, on two opposing sides: on one side of the river is Empresa, on the other side, Penápolis. Empresa is characterized as a place of vice and Penápolis is the place of virtue. In this idealized scenario of Rio Branco city, the State of Acre and the Amazon region, dreamed by the author, set the stories of Solon, son of Colonel João Gonçalves, and Rubina, a black prostitute. It is also between vice and virtue that Abguar Bastos narrates the stories of other characters 
who were marked, physically and morally, by the "chorus of failed and suffering": the Acrean region. From a deterministic view, such characters appear in the eyes of the readers subjectivities as degraded beings and condemned to suffer in "the deep realm of solitude".

KEYWORDS: Literature. Acrean Amazon. Discourse. Identity.

\section{REFERÊNCIAS}

ALBUQUERQUE JÚNIOR, D. M. A Invenção do nordeste e outras artes. 4a ed. São Paulo/ Recife: Cortez/ Massangana, 2009.

BHABHA, H. O Local da cultura. Tradução de Myriam Ávila, Eliana Lourenço de Limas Reis e Gláucia Renate Gonçalves. Belo Horizonte: Ed. UFMG, 2005.

CUNHA, E. Um Paraíso perdido: ensaios, estudos e pronunciamentos sobre a Amazônia. Organização, introdução e notas de Leandro Tocantins. Rio de Janeiro/Rio Branco: José Olympio; Fundação de Desenvolvimento de Recursos Humanos, da Cultura e do Desporto do Governo do Estado do Acre, 1986.

DAMASCENO, A. B. Certos caminhos do mundo: romance do Acre. Rio de Janeiro: Hersen - Editor, 1936.

GONDIM, N. A Invenção da Amazônia. São Paulo: Marco Zero, 1994.

VILELA, E. Corpos inabitáveis. Errância, filosofia e memória. In: LARROSA, J. \& SKLIAR, C. (Orgs.). Habitantes de Babel: políticas e poéticas da diferença. Tradução de Semíramis Gorini da Veiga. Belo Horizonte: Autêntica, 2001.

PRAT, M. L. Por uma perspectiva crítica feminista, entrevista à Cláudia de Lima Costa e Alai Garcia Diniz, Seção Ponto de Vista, Revista Estudos Feministas, v.07 n.01-02, Florianópolis, 1999, disponível em: http://educa.fcc.org.br/pdf/ref/v07n01-02/v07n01-02a09.pdf

SAID, E. Cultura e imperialismo. Tradução de Denise Bottman. São Paulo: Cia das Letras, 1995.

SARLO, B. Paisagens imaginárias: intelectuais, arte e meios de comunicação. Tradução de Rubia Prates e Sérgio Molina. São Paulo: Edusp, 1997. 